\title{
The Role of Symbols in Social Movements
}

\author{
Orges Zani \\ $\mathrm{PhD}$ Candidate, European University of Tirana,
}

\begin{abstract}
This paper analyzes the birth of VETVENDOSJE as a social movement through different symbolic representations. Based on the theoretical model of symbolic interaction the study will analyse how the Network Action for Kosovo, created as a counter response against the Serbian dictatorship in Kosovo, continued its actions by creating the slogan "NO NEGOTIATION- VETVENDOSJE", collecting signatures by the citizens and requiring to UNMIK, to investigate on the destiny of numerous Albania disappeared during the war by the Serbian Army. UNMIK did not take into consideration the petition because it was more interested in the development of institutional conversations to define the judicial status of Kosove. This made the followers of VETVENDOSJE to put the big slogan in front of the UNMIK building "NO NEGOTIATION-VETVENDOSJE! The appearance of this slogan transformed the network into the VETVENDOSJE movement and in the same time it made possible the idea that people will have their right to decide on the judicial and political sovereignty of Kosovo. This slogan had strong conceptual and emotional power on its followers and incited numerous protests and public meetings. From this we can conclude that symbols and their symbolic representations serve perfectly for the creation social movements.
\end{abstract}

Keywords: Contradicting Serbian dictatorship, UNMIK, the petition, the slogan, protests and public gatherings

\section{Introduction}

Most of physiological, psychological or socio-cultural concerns of people or groups derive by the use of physical or non physical violence that they suffer by another man, group or social or other state institution that wants to impose to the first group the behaviors and believes of the second. This happens because the presence of the features and different attitudes of the first group, even in the case when do they not show any open challenging or attacking signs, are perceived as a possible danger for the second group, as long as the characteristics of the first group are considered to be unknown and a threat for the second one.

Putting the situation of both parts in a context, the third party, will try to take measures to defend it or at least to counter act to this problem just to defend their lives, values and relationships that have consolidated this social-cultural group. Said this, while the creation of meaning and collective belongings within socio-cultural groups or social movement comes derives from common physiological and psycho-cultural symbols such as language, flag, race, folklore, myths, traditions, customs etc. and their preservation should be based on their symbolic representation every time their characteristics and attitudes are endangered by other threating groups. Based on the theoretical model of symbolic interaction, applied in the case of VETVENDOSJEMovement, this paper wants to affirm the idea that the birth of a social movement can happen through the use of symbols and their expressive language. It was the open contradiction against the dictatorship and occupation of Kosovo from Serbia, the moment that formalized the creation of Network of Action for Kosovo and that later on composed petition that required UNMIK to blame Serbian state structures for the numerous lost lives and to make it responsible for finding the missing bodies. The refusal and lack of an answer to fulfill this human right by those who were concerned only about the judicial status of Kosovo through institutional and international talks, made the followers to take further symbolic actions. The slogans put in front of the UNMIK building "NO NEGOTIATION- VETVENDOSJE! - made clear that the international bodies were not only disrespecting the basic rights and liberties of a nation but also signaled the transformation of the Network of Action in VETVENDOSJE movement, a movement that would incite an active and 
continuous communication in defining and assessing the common goals of those who were part of the movement (Gumperz, 1982). Still it was not clear if these symbols would encourage protests or further public gatherings.

\section{The objection against the Serbian dictatorship, drafting the petition for war missing peoples and encouraging protests against UNMIK}

In the 1990, after the fall of Yugoslavia, the people of Kosovo were faced with a continuous socio- political and ethnocultural violence by the Milosevic state institutions. While Croatia and Bosnia-Hercegovina were fighting against Serbs, for Kosovo was even more difficult because it did not have the status of a republic or the status of an autonomous country within the federation.

However, inspired by the example of them to defend the rights and liberties of a nation and it could be free only by the often articulation of symbolic signs such as the nation, language, traditions etc. and their use to encourage different forms of action or organization, people in Kosovo started to use this symbols more and more. Quite often the first reactions on social-cultural and ethno-cultural problems have had and still bear some symbolic uses. These symbolic uses express both the nature and content of a given issue and inculcate irreversible images in the mindset and imagination of those people or social groups that are affected by these problems. Those images are more than necessary to encourage people to become part of a movement. Same stands true for Kosovo as well if we remember that:

The beginnings of VETVENDOSJE are to be found in several actions taken by the Network of Action for Kosovo, actions that aimed to create an active society in this country and to make people aware about the cause and encourage them to defend universal rights, human liberty and social justice. Found in 1997, by a bunch of international activists leaded by the American writer Alice Mead, this network started its actions by supporting citizen protests against the occupation and Serbian dictatorship such as the support for the creation of the Independent Union of Pristina University Students and their non-violent protests for the liberation of university space and buildings (the history of VETVENDOSJE Movement!: 1)

The Network of Action for Kosovo, founded to support and defend liberties and human rights of those oppressed by the Serbian dictatorship, together with the expressive and active articulation against this dictatorship, could be seen as contextualizing and essential data in understanding the creation of meanings that influenced those communicative behaviors of participation and evaluation(Green \& Smith, 1983). Under these conditions this network was announced to be an acting subject against these oppressions. It contains two main criteria: "first that this network requires the mobilization of those who were not and secondly its opponent is to be found outside its supporters" (Gamson, 1990: 14-17).

While we see this meaning to be created and calcified, all attention is paid to its possibility to expand and use its influence in favor of its continuance in documenting the Serbian crimes during the war and achieve to conduct a whole campaign asking the liberation of war hostages, in 1999-2000 (History of VETVENDOSJE Movement!: 1). In July 2003, it was decided that the network main office would be in Kosovo. They decided to draft a petition wanting to find the lost people during war and they collected 236.311 signatures ( History of VETVENDOSJE Movement!:1) giving life to a voluntary union of people who wanted to change the society for good (McCarthy \&Zald, 1973). The use of this sign, the petition, was all inclusive and made the network involve many people who were supporting this movement (McCarthy \&Zald, 1973a). For Anderson, the approach towards this new context, both in space and time and in symbolic signs "likely will exercise a considerable influence on the continuity of the group structure and in the results of interaction" (Anderson, 1976: 209). Such delineations ought to be analyzed together with some actions in time not only to spread and expand the support of its meaning but to create a discrepant reality with the existing one. This together with the placement of the lost people' photos in front of the Parliament and Government of Kosovo (History of VETVENDOSJE Movement!: 1), are proofs of a nation convictions and beliefs of people that want to change some elements of the social structure and to make justice in a society (McCarthy \&Zald, 1977). The problem is that we need more to undertake collective actions to change the social structures and responsible institution than to deal with the international body, the Serbs or the local governors to accept their moral responsibilities for the massacres (Zald\& Ash, 1966), a responsibility that seems to be not accepted by them at all by any of them.

Organizing families of those who were lost together with the appearance of accusing notes, in slogans against people who were responsible for murders and massacres happened in Small Krusha, in Gjakova and in Recak ( History of VETVENDOSJE Movement!: 1), gave a boost to the symbolic delineation. Responsible for the declared indifference of the 
international body and the Serbs in terms of legal punishment of those who commit those human massacres, in 10 June 2004, activists decided to protest in front of the UNMIK building with music, holding in hand red cartons, declaring themselves citizens and activists and promising that they would fight against the anti -democratic regime of this institution (History of VETVENDOSJE Movement! : 1). Together with the strong sense that these protests would continue, the participation was being shaped as a "political" action against some policies or conditions that are unacceptable (Lipsky, 1968). In this moment the network in collaboration with some organizations such as "The call of mothers" from Gjakova, " 26 March 1999" from the Small Krusha and other familiars of the victims of Recak, - on 26 March, 7 May and 10 June 2005- put three huge placards in the buildings of UNMIK (History of VETVENDOSJE Movement! : 1) . This situation becomes a condition in understanding those symbolic signifiers in the form of an agreement through which the meaning is communicated in action (Tannen, 1984), for the simple fact that the first placard had on it the names of 56 people who were accused for the assassination and hostage of 112 people from Small Krusha: the second one had the names of 35 people who were accused for killing 750 persons from Gjakova and taking hostage 680 other inhabitants, who are still missing: the last placard had on it the names of 20 people who were accused to be responsible for the massacre of 42 people in a village, in Recak (History of VETVENDOSJE Movement! :1-2). Followed by a second wave of protests- named "All are being missed" and with the support of "The call of mothers" organization- the names of all lost people were shown in ten huge stands, placed in 10 most well lit parts of the capital, despite their ethnicity, religion or other features (History of VETEVENDOSJE Movement!: 2). Such codification did not only create the feeling of familiarity among activists and supporters but also avoided any ethnic or religious fragmentation in the names of the lost people, under the slogan that all are being missed, unified all individuals with the cause that these people were killed.

\subsection{The slogan "NO NEGOTIATION- VETVENDOSJE! - An incentive for the creation and continuance of movement through protests and public gatherings.}

Aiming to motivate more action among activists and supporters, in 12 June 2005, it was decided to put in the walls of UNMIK the slogan "NO NEGOTIATION- VETEVENDOSJE (Historiku i VETVENDOSJE Movement!: 2). This slogan would not only transform the Network of Action for Kosovo into VETVENDOSJE movement but it would include an immediate and continuous communicative process that would negotiate membership and interactive role of each of participants (Gumperz, 1982a). Said this, we could question how and how much would these premises influence the further organization of the movement, giving path to the creation to a more intensifying relationship between the movement and its supporters. Tracing down these symbols opens a path for a more inclusive social movement, saying that an initiative does not only need signifiers and their graphic representation; even though they are easy to memorize and to create meaning in the same time they create in people's mind memories and experiences related to a figure or a group of symbolic gestures, something which is more difficult to be transmitted by language that cannot create memory and emotions through its vocal articulation.

A movement to continue as such, it needs participation and the ability to put in action encouraging tools that would improve its continuity. The slogans written in 12 June 2005 were banned by the state police two days later and in the same day 12 activists re-write them, an act that put them under arrest by the police ( NO NEGOTIATION- VETEVENDOJE! 14 June 2005)

Days later, $27^{\text {th }}$ of June, VETVENDOSJE Movement protested against the visit of VukDrashkovic in Kosovo, who was responsible for crimes committed by Serbians in Kosovo as he was the vice prime minister of ex-Yugoslavia during the bombards. He was also known for his neo-fascist and ethnic ideologies (400 eggs against Drashkovic, 27th June 2005).

In a certain way this protesting action mirrors the expression of concerns for the institutions (Turner, 1969) that direct Kosovo and also shows an injustice (Turner 1960a) by this or other Serbians during the war in Kosovo. Pronouncing and continuing the movement by identifying and aiming to solve some important problems- as is the case of not accepting any of the negotiations in defining the status of Kosovo by the international bodies and basing itself to the power of voting by the people of Kosovo- the movement did not only formalized its activity but also legitimated itself as an actor and a factor of change in the country. This means that the movement becomes part of politics and stands against the bad government. A common action within the movement is created by the requests and goals that are declared from this side and on the other side stands the government or the international body that wants to put down this request (Tarrow, 2001), legitimizing this continuous polarization. 
In $20^{\text {th }}$ July 2006, some activists were beaten and then attacked by fuel substances, by the police because together with other activists they wrote down some slogans (Kerbac and spray for activists in Shtime, 20th July 2006). This and other events showed that the movement and activists were violated, something that made this political confrontation more colorful (Tarrow, 2001a). To create a sense of support and all inclusive approach of the movement in this first stage, it decided to focus its actions on public gatherings and debate with the people around Kosovo; in 12 August in Kacanik, 14 August in Prizren, 15 August in Lipjan and 16 August in Klive, VETVENDOSJE activists! Organized meetings with citizens in public places, discussing political and social developments in Kosovo (Meetings and Slogans, 16 August 2005)

The use of this tool by the movement is seen as a technique to make citizens conscious about the necessity to know and solve their problems and also to increase the support of people for the movement. The development of debate carries some specific meanings- " terms that label objects and daily life tools, needs and request (Marcuse, 2006: 107)-, giving a chance to the movement to be modeled according to the sustainable scheme of Beginning, Answer and Assessment (Mehan, 1979). This means that by offering an opportunity to identify and treat the causes and the content of problems, gives way the chance to understand the consequences that these problems would bring in a larger scale for the whole society. Knowing the causes and consequences of problems, through public gatherings, people become more conscious for them. The issue is that consciousness does not solve these people's troubles, something that would require the support in protests that would lead to the solutions of these problems. It is this sense that makes VETVENDOSJE Movement capable to delineate its activity based on meetings, the creation of centers in the whole territory and the protests. $\ln 15^{\text {th }}, 16^{\text {th }}$ and $17^{\text {th }}$ of September 2005, were held several meetings and were founded centers of this movement in Viti, Dardane and Besiane (Meetings, Slogans, New Centers of VETVENDOSJE! 17 th September 2005). In 21th September was organized a protest against the visit of SandaRashkovic ( head of coordinating office in Serbia for Kosovo and Metohine) in Kosovo, given that she emphasized before coming that we can start conversations only if we all agree that Kosovo is a Serbian territory (Against the visit of SandaRashkovic, 21th September 2005)

To expand its influence and its participants, the movement went out the urban areas, trying to reach the suburbs, organizing meetings in rural areas such as the meeting in Rugova in $25^{\text {th }}$ September, where were discussed some political problems of the country (Rugova and Mitrovica, 25 September 2005), while in 22th of October 2005, some activists held a meeting with some villagers of Korishta, explaining the negative processes that were being organized against Kosovo ( Public meetings in Korisht and in Prizren, 22th October 2005), describing the movement as an active enterprise to earn what was being taken by the political system (Lipsky, 1968a). These two types of actions, the debates and the protests, clarifies the idea that even though the activists are not capable to immediately transform the conditions they are living due to lack of resources, it is important that they are there to perform actions that attract the attention of many people who can later organize themselves in groups to solve these problems and who can support further the movement and its goals (Turner, 1969b).

\section{Conclusions and suggestions}

Each small or large socio-political, socio-cultural or ethno-cultural group within or outside the territory of a country, is created based on a meaning that is defined by the physiological features and other ethno -cultural or socio-political characteristics that its members think and affirm as common in comparison with other groups. Usually, when the physiological or ethno-culturalsymbols that encourages the content modeling of relationships among its members are endangered or threated by the attacks of another ethno-cultural group who might aim to disappear the psycho-dynamic symbols through which are created and developed daily activities of this group. When faced with this, the only way to defend its continuity is by the unification of all members in a group through the symbols they declare to signify this common sense. If yesterday, the continuity of one group was not threatened by the other group, the least that could happen was that the two groups recognized their symbolic representations based on time, space and judicial orders. But in the case that one group attempts to serve and exercise these symbolic values through their legitimization in another judicial order, as was the case of Slovenia, Croatia and Bosnia- Herzegovina claiming independence in the 1990, convicted that their ethno-cultural symbols would be threatened or even cease to exist if they would allow the Serbian hegemony. The bigger group would try to justify its pressure against small groups, requiring the exercise of symbolic values and their relationships within this judicial order, even though the small groups would still believe that they will be destroyed by them. The bigger group will also try to attack directly, physically or emotionally the small groups, aiming to create and preserve their psycho -cultural and ethno -cultural hegemony within a given region. More or less, taking in consideration the massacres, 
genocides and ethnic cleansing that happened in Croatia, Bosnia-Herzegovina and in Kosovo that experienced the same calamities, it was created the conviction that keeping Yugoslavia alive through the dictatorship of Milosevic was nothing but a legitimization and imposition of the Serbian ethno and psycho cultural symbols on smaller countries that were part of this federation. In this perspective, this paper tried to explain why it was important to keep alive, use and encourage ethno, socio and psycho -cultural symbols to create a social movement that would fight for human rights of a nation, the nation of Kosovo, stressing out the loss of people and the punishment of those who took part on these massacres, genocides and massive ethnic cleansing, giving to Kosovo and to its people the right to decide for themselves, its independence and forms of state organizations. Even though these points were never fulfilled, it is important to emphasize that through the articulation, use and organizational incentives that these symbols had, was created a social movement, called VETEVENDOSJE, who has served and it is still serving as an actor and real political factor, being politically represented in the Parliament, continuing to control the good functioning of ethno-cultural, state, socio-political and socio-economical relationships in Kosovo.

\section{References}

[1] Anderson, B. (1976) "Perspectives on the role of an interpreter", nw R. Brislin (ed.) Translation: Application and Research,New York: Gardner, f. 208-225.

[2] Gamson, W. A. (1990) The Strategy of Social Protest, Belmont, CA: Wadsworth Publishing Company.

[3] Green, J \& Smith, D. (1983) "Teaching and learning: A linguistic perspective", The elementary school journal, 83 (4), f. 352-391.

[4] Gumperz, J. (1982, 1982a) Discourse Strategies, Cambridge: Cambridge University Press.

[5] Lipsky, M. (1968, 1968a) "Protest as a Political Resource", American Political Science Review, 62 (4), f. 1144-1158.

[6] Marcuse, H. (2006)Njeriunjë dimensional,Tiranë: Plejadë.

[7] McCarthy, J. D \&Zald, M. N. (1973, 1973a) The Trend of Social Movements in America: Professionalization and Resource Mobilization, Morristown, NJ: General LearningCorporation.

[8] McCarthy, J. D \&Zald, M. N. (1977). "Resource Mobilization and Social Movements: A Partial Theory", American Journal of Sociology, 82 (6), f. 1212-1241.

[9] Mehan, H. (1979) Learning Lessons: Social Organization in the Classroom, Cambridge, MA: Harvard University Press.

[10] Tannen, D. (1984) Conversational Style: Analysing Talk among Friends, Norwood, N.J: Ablex.

[11] Tarrow, S. (2001, 2001a) "Silence and Voice in the Study of Contentious Politics: Introduction" nwR. R. Aminzade\& J. Goldstone \& D. McAdam\& E. J. Perry \& W. H. Sewell Jr\& S. Tarrow\& C. Tilly (eds) Silence and Voice in the Study of Contentious Politics. Cambridge:Cambridge University Press, f. 1-13.

[12] Turner, R. H. (1969, 1969a, 1969b) "The Public Perception of Protest", American Sociological Review, 34 (6), f. 815831.

[13] Zald, M. N \& Ash, R. (1966) "Social Movement Organizations: Growth, Decay and Change", Social Forces, 44 (3), f. 327-341.

[14] LëvizjaVetëvendosjeHistoriku i Lëvizjes VETËVENDOSJE!.Seen inwww.vetevendosje.org /publications/documents (available).

[15] LëvizjaVetëvendosje (2005) JO NEGOCIATA-VETËVENDOSJE!, 14 June 2005. Seen in www.vetevendosje.org Inews (available).

[16] LëvizjaVetëvendosje (2005) Kërbaçdhe spray lotësjellëspëraktivistëtnëShtime, 20 July 2005.Seen inwww.vetevendosje.org /news (available).

[17] LëvizjaVetëvendosje (2005) KundërvizitëssëSandaRashkoviç-it, 21 September 2005.Seen in www.vetevendosje.org Inews (available).

[18] LëvizjaVetëvendosje (2005) NëRogovëtëHasitdheMitrovicë, 25 September 2005.Seen inwww.vetevendosje.org /lajme 9available). 
[19] LëvizjaVetëvendosje (2005) TubimedheParrulla, 16 August 2005 Seen in www.vetevendosje.org /news (available).

[20] LëvizjaVetëvendosje (2005) Tubime, parrula, Qendratërejatë VETËVENDOSJE!-s, 17 September 2005. Seenwww.vetevendosje.org /news (available).

[21] LëvizjaVetëvendosje (2005) TubimepublikenëKorishtëdhePrizren, 22 October 2005.Seen www.vetevendosje.org Inews (available).

[22] LëvizjaVetëvendosje (2005) 400 vetëprishurakundërDrashkoviçit, 27 October 2005.Seen inwww.vetevendosje.org Inews (available). 